\title{
Conservative Working Capital Policy: Can it Increase Profitability and Sustainable Growth Rate?
}

\author{
Sunardi Sunardi ${ }^{*}$, Asti Ayuk Putri Pertiwi ${ }^{\text {b }}$, Supramono Supramonoc \\ a *University of Merdeka Malang \\ ${ }^{\mathrm{b}, \mathrm{c}}$ Satya Wacana Christian University, Indonesia \\ a* Corresponding Author: nardisu92@yahoo.com
}

Article History: Received: 10 November 2020; Revised 12 January 2021 Accepted: 27 January 2021; Published online: 5 April 2021

\begin{abstract}
The objective of this study is to investigate the effect of conservative working capital policy on profitability and examine the effect of conservative working capital policy on sustainable growth mediated by profitability in the manufacturing sector in Indonesia. This study involves 133 manufacturing firms in Indonesia during the 2013-2018 period. Data are analyzed using panel data regression with random effects estimation models. The result of this study showed that conservative working capital policy, both investment and financing policy, has proven to have a positive effect on sustainable growth rate. Besides, this study also proved that profitability has a positive effect on SGR. Furthermore, there was the effect of conservative working capital policies on the level of sustainable growth through profitability. This study not only contributes to expanding knowledge about the relationship between working capital policies, profitability and sustainable growth rates, but also has relevant implications for firm managers to improve firm performance to be able to grow sustainably..
\end{abstract}

Keywords: working capital policy, profitability, sustainable growth rate, pecking order theory

\section{Introduction}

So far, the financial literature has paid more attention to investing in financial instruments rather than investing in the firm's real assets. The two are actually interrelated. Investment in real assets will determine the prospects of firms that attract investment in financial instruments issued by an attractive firm or not. For investment in the firm's real assets in the form of current assets depends on the orientation of the working capital policy. There are two types of policies namely; (a) conservative, if the firm chooses a low proportion of current asset investment and (b) aggressive, if the firm chooses a low proportion of asset investment (Gitman \& Chad, 2012). This type of policy also applies to short-term financing. The firm has a conservative working capital financing policy if the firm chooses a low proportion of short-term financing and an aggressive financing policy if the proportion of short-term financing is high. A conservative working capital policy has the potential to increase profits but face a high liquidity risk. Conversely, an aggressive working capital policy has the potential to reduce profitability but has a low liquidity risk. However, this argument argues is still debatable given the empirical level, many studies in several countries that prove that conservative working capital policies have a positive effect on profitability (Nazir \&amp; Afza, 2009; Raheman et al., 2010; Adam et al., 2017; Nastiti, 2019).

Through a conservative working capital policy allows firms to adopt soft credit sales policies that will spur sales growth. It is expected that sales growth will result in a significant increase in profits. Firms to achieve sales growth should rely more on internal financing support so they do not experience serious financial difficulties (Fonseka et al., 2012). Furthermore, the availability of internal financing depends on the firm's ability to generate profits. Thus, there is a relationship between sales growth, profits, and internal financing. In line with this thinking, Higgins (1977) has introduced the concept of sustainable growth rate (SGR) which refers to the maximum level of sales growth that can be achieved by a firm based on internal financing capabilities. Firms that operate with sales growth rates above SGR have the potential to experience financial distress and even bankruptcy due to holding excessive leverage (Kumar, 2018). Meanwhile, sales growth is far below SGR, the firm has the potential to experience the risk of slow or even stagnant growth. Several previous studies have proven the positive effect of profitability on SGR (Amouzesh et al., 2011; Rahim, 2017; Manaf et al., 2018; Nastiti et al., 2019). To the best of our knowledge, no studies are investigating the effect of conservative working capital policies on sustainable growth. There is a possible influence of conservative working capital policies on sustainable growth mediated by profitability.

This study aims to examine the effect of conservative working capital policy on profitability and examine the effect of conservative working capital policy on sustainable growth mediated by profitability in the manufacturing 
sector in Indonesia. This sector in developing countries has become the backbone of economic growth. Also, the manufacturing sector has been oriented towards conservative policies (Nastiti, 2019; Deloof, 2003; Ahmad \& Samim, 2018). This research contributes to filling the research gap regarding the relationship between working capital policies and sustainable growth rates. While practically, the results of this study are expected to help firms to improve firm performance through working capital policies

\section{Literature Review}

\subsection{Working capital policies and profitability}

Working capital policy concerns the proportion of investment in current assets and short-term financing chosen by the firm (Gitman \& Chad, 2012). Working capital policies relating to the proportion of current assets are referred to as working capital investment policies. Meanwhile, policies related to financing through short-term debt are called working capital financing policies (Bandara, 2015). A conservative working capital investment policy is indicated by the proportion of current assets to total assets that tend to be higher. While conservative working capital financing policies, firms tend to have a low proportion of short-term debt. The determination of the type of working capital policy faces a trade-off between risk and profitability.

The firm's conservative policies have low liquidity risk but low profitability (Islam \& Mili (2012 Hassani \& Tavosi, 2014).) Firms that take this policy in order to maintain liquidity tend to invest in large current assets and rely more on long-term financing rather than the short term so that it increases the cost of capital and results in lower profits. However, previous studies have mixed results. Several studies have found the influence of aggressive investment policies to have a positive impact on profitability (Al-Shubiri, 2010; Puraghajan et al., 2014; Kishore \& Pai, 2014). Similarly, aggressive financing policies also increase profits (Ogundipe et al., 2012; Oloo \& Mwangi, 2014; Mwangi et al., 2014; Adam et al., 2017).

Meanwhile, other studies have found that conservative investment policies have a positive influence on profit (Abdoli et al., 2013; Sohail et al., 2016; Rasyid et al., 2018). In the context of conservative financing policies, it also shows a positive effect on earnings (Vahid et al., 2012; Panigrahi, 2014; Kishore \& Pai, 2014; Wanguu, 2015). There are several possibilities why conservative capital policies have a positive effect on profits, among others, firms can carry out working capital management that is measured through an optimal cash conversion cycle (Sohail et al., 2016) and underdeveloped money market conditions that cause firms to have limited access to financing cheap short-term (Thakur \& Muktadir-al-mukit, 2017). In addition, the possibility for firms to spur sales growth relies on a soft credit policy so that the firm will have large account receivables (Wilner, 2000) and have a large amount of inventory to avoid stock-outs (Corsten \& Gruen, 2004)

\subsection{Sustainable Growth Rate}

The firm's sales growth is a very important performance benchmark for a firm (Mukherjee \& Sen, 2018). However, sales growth must be balanced with the firm's financing capabilities. The firm needs to explain the sales growth target that the firm wants to achieve to avoid financial difficulties due to excessive leverage and to bear high capital costs. Higgin (1997) introduces the concept of SDR which refers to the maximum level of sales growth that a firm should achieve when a firm maintains its capital structure and dividend payout targets. Financing needs for the sake of sales growth do not rely on excessive debt addition or issuance of new shares. Thus, firms will rely more on their ability to generate internal financing. This is also in line with SGR in line with the pecking order theory which explains that taking into account the low cost of capital the firm has prioritized internal financing sources rather than external financing such as debt and issuance of new shares. Firm preference for issuing shares as the last alternative financing if the firm does not have sufficient internal finances and the firm also cannot obtain new debt (Palombini \& Nakamura, 2011).

SGR can help managers to do financial planning (Rădăşanu, 2015) even in the interests of control and performance. By knowing SGR, firms can plan their growth targets based on their financing ability so as not to impact on negative cash flow (Ashta, 2008) and avoid financial difficulties that can lead to bankruptcy (Fonseka et al., 2012). SGR can be used as an instrument of control so that firms do not only pursue growth in sales solely. Besides, SGR can be a measure of the extent to which a firm has utilized its assets efficiently and can generate profits as a source of internal financing so that the firm will be able to grow sustainably.

SGR is a combination of operational and financial elements (Amouzesh, Moeinfa \& Mousavi, 2011). The constituent elements of SGR are return on equity (ROE) and retention rate (Higgin, 1917). ROE refers to the firm's ability to generate profits. While the retention rate refers to the proportion of retained earnings towards net income. As such, SGR depends on profitability and the proportion of profit that is not distributed to shareholders as dividends. Previous studies (Amouzesh et al., 2011; Rahim, 2017; Manaf et al., 2018; Nastiti et al., 2019) have provided evidence that profitability has a positive effect on SGR. As stated earlier there is a relationship between conservative capital policies and profitability. Although this policy causes a longer cash cycle, it has a positive 
impact on earnings. This is also supported by the results of the study by Nastiti et al. (2019) which shows that the cash cycle has a positive impact on profits. Furthermore, profit has a positive effect on SGR (Nasim \& Imama, 2015). Based on the above thinking, conservative working capital policies may influence the increase of SGR through profitability.

\section{Methods}

The population of this study is 165 firms in the manufacturing sector which are listed on the Indonesia Stock Exchange (IDX). The aspect underlying the selection of manufacturing firms is the relatively large proportion of current assets that can even reach more than half of total assets. Based on the criteria that the financial statements are (a) presented in rupiah and, (b) found items needed to measure the research variables obtained a sample of 133 firms. The data used in this study is the annual report downloaded from the website of the IDX (http://www.idx.co.id) and the official website of the firm concerned.

This study involves a conservative working capital policy as an independent variable. The greater the proportion of current assets and the lower the proportion of short-term debt to total assets, the firm tends to adopt a conservative working capital policy. Furthermore, profitability acts as a mediating variable and SGR as the dependent variable. Moreover, this study involves several control variables; firm size, sales growth, and total turnover assets. Measurement of each variable is presented in the following tab

Tabel 1. Variable measurement

\begin{tabular}{|c|c|}
\hline Variable & measure \\
\hline Sustainable Growth Rate (SGR) & ROE $\times$ Retention Rate \\
\hline \multicolumn{2}{|l|}{ Working capital policy: } \\
\hline \multirow{2}{*}{ 1. Investment Policy (IP) } & Total Current Assets \\
\hline & Total Assets \\
\hline \multirow[t]{2}{*}{ 2. $\quad$ Financing Policy (FP) } & Total Current Liabilities \\
\hline & Total Assets \\
\hline \multirow[t]{2}{*}{ Profitability } & Net Income \\
\hline & $\overline{\text { Total Assets }}$ \\
\hline Firms Size (FRSIZE) & log total assets \\
\hline \multirow[t]{2}{*}{ Sales Growth (SALESGR) } & sales $_{\text {it }}-$ sales $_{\text {it-1 }}$ \\
\hline & sales $_{\text {it-1 }}$ \\
\hline \multirow[t]{2}{*}{ Total Asset Turnover (TATO) } & Sales \\
\hline & Total Assets \\
\hline
\end{tabular}

This study uses panel data regression. Consider the aim of the study, three estimation models were formulated. Model 1 estimates the effect of working capital investment policies in current assets (IP) and short-term financing (FP) on profitability. Model 2 predicts the effect of profitability on SGR. Model 3 estimates the indirect effect of IP and FP on SGR through profitability.

$$
\begin{aligned}
& \text { ROA }_{\mathrm{it}}=\beta_{0}+\beta_{1} \mathrm{IP}_{\mathrm{it}}+\beta_{2} \mathrm{FP}_{\mathrm{it}}+\beta_{3} \text { SALESGR }_{\mathrm{it}}+\beta_{4} \mathrm{FRSIZE}_{\mathrm{it}}+\beta_{5} \mathrm{TATQ}_{\mathrm{t}}+\varepsilon_{\mathrm{it}} \\
& \mathrm{SGR}_{\mathrm{it}}=\beta_{0}+\beta_{1} \mathrm{ROA}_{\mathrm{it}}+\beta_{2} \mathrm{SALESGR}_{\mathrm{it}}+\beta_{3} \mathrm{FRSIZE}_{\mathrm{it}}+\beta_{4} \mathrm{TATQ}_{\mathrm{t}}+\varepsilon_{\mathrm{it}} \ldots \ldots \ldots \ldots \ldots \ldots \ldots \ldots \ldots \\
& \mathrm{SGR}_{\mathrm{it}}=\beta_{0}+\beta_{1} \mathrm{IP}_{\mathrm{it}}+\beta_{2} \mathrm{FP}_{\mathrm{it}}+\beta_{3} \mathrm{ROA}_{\mathrm{it}}+\beta_{4} \mathrm{SALESGR}_{\mathrm{it}}+\beta_{5} \text { FRSIZE }_{\mathrm{it}}+\beta_{6} \text {TATO}_{i t}+\varepsilon_{i t}
\end{aligned}
$$

\section{DTEMiscussion}

\subsection{Analysis}

Table 1 shows that the average SGR of manufacturing firms in Indonesia during the 2013-2018 period was only $1.9 \%$. Current assets investment reached $54.2 \%$ and short-term financing amounted to $32.2 \%$ so there are indications that it leads to conservative policies. The ability to generate an average profit (ROA) of 5.5\%. The average sales growth reached $10.4 \%$, far more than SGR. The level of assets utilization to generate sales (TATO) of 1,058. Meanwhile, the average value of total assets (FRSIZE) is Rp. 8.1 trillion. 
Table 1. Descriptive statistics

\begin{tabular}{lllll}
\hline Variable & Mean & Std. Dev & Min & Max \\
\hline SGR & 0.019 & 0.378 & -6.433 & 1.426 \\
IP & 0.542 & 0.188 & 0.033 & 0.960 \\
FP & 0.322 & 0.181 & 0.010 & 0.971 \\
ROA & 0.055 & 0.096 & -0.392 & 0.716 \\
SALESGR & 0.104 & 0.355 & -0.980 & 5.947 \\
TATO & 1.058 & 0.704 & 0.003 & 8.429 \\
FRSIZE* & 8059016.000 & 27960341.000 & 89327.000 & 344700000.000 \\
\hline
\end{tabular}

Note: $*$ in millions of rupiah

Source: Secondary data processed

Relationships between variables are presented in the Pearson correlation matrix in Table 2. There is a positive relationship between SGR and ROA (0.433). ROA also is positively related to IP (0.265) and negatively to FP ($0.133)$. In addition, the correlation coefficient between explanatory variables tends to be low. This can indicate that there is no multicollinearity problem because it is below 0.80 (Kumari, 2008)

Tabl2 2.Correlation matrix

\begin{tabular}{|c|c|c|c|c|c|c|c|}
\hline & SGR & IP & FP & ROA & FRSIZE & SALESGR & TATO \\
\hline SGR & 1 & & & & & & \\
\hline IP & $\begin{array}{l}0.220 \\
* * *\end{array}$ & 1 & & & & & \\
\hline FP & $\begin{array}{l}-0.091 \\
* *\end{array}$ & $\begin{array}{l}0.265 \\
* * *\end{array}$ & 1 & & & & \\
\hline ROA & $\begin{array}{l}0.432 \\
* * *\end{array}$ & $\begin{array}{l}0.260 \\
* * *\end{array}$ & $\begin{array}{l}-0.133 \\
* * *\end{array}$ & 1 & & & \\
\hline FRSIZE & 0.014 & $\begin{array}{l}-0.232 \\
* * *\end{array}$ & $\begin{array}{l}-0.077 \\
* *\end{array}$ & $\begin{array}{l}0.183 \\
* * *\end{array}$ & 1 & & \\
\hline SALESGR & $\begin{array}{l}0.074 \\
*\end{array}$ & 0.007 & 0.043 & 0.027 & -0.006 & 1 & \\
\hline TATO & $\begin{array}{l}0.135 \\
* * *\end{array}$ & $\begin{array}{l}0.387 \\
* * *\end{array}$ & $\begin{array}{l}0.295 \\
* * *\end{array}$ & $\begin{array}{l}0.267 \\
* * *\end{array}$ & -0.054 & $\begin{array}{l}0.085 \\
* *\end{array}$ & 1 \\
\hline
\end{tabular}

Notes: * significant at 10\%, ** 5\%, ***1\%

There are three tests to choose the appropriate panel data estimation model. First, the Chow test was conducted to compare the common effects and fixed effects regression models. Second, the Hausman test for choosing between fixed-effects or random-effects models. Third, the Lagrange Multiplier test is used to choose between random effects and common effects models. Table 3 shows that the test results show that the more appropriate estimation model is the random effect.

.Tabel .3.Alternative estimation model

\begin{tabular}{lllll}
\hline \multirow{2}{*}{ Model } & Prob. & & & Best Estimation \\
\cline { 2 - 4 } & $\begin{array}{l}\text { Chow } \\
\text { Test }\end{array}$ & $\begin{array}{l}\text { Hausman } \\
\text { Test }\end{array}$ & $\begin{array}{l}\text { Lagrange } \\
\text { Multiplier } \\
\text { Test }\end{array}$ & $\begin{array}{l}\text { Model } \\
\text { Mandom effect }\end{array}$ \\
\hline 1 $(\mathrm{IP}+\mathrm{FP} \rightarrow \mathrm{ROA})$ & 0.000 & 0.175 & 0.000 & Random effect \\
2 $(\mathrm{ROA} \rightarrow \mathrm{SGR})$ & 0.000 & 0.602 & 0.000 & Random \\
$3(\mathrm{IP}+\mathrm{FP}+\mathrm{ROA} \rightarrow \mathrm{SGR})$ & 0.000 & 0.269 & 0.000 & Random effect \\
\hline
\end{tabular}

Source: Secondary data processed

This study will examine the effect of conservative working capital policies which include current asset investment policies and short-term financing policies on profitability and SGR. As stated in the previous section, the best model in this study is the random effect, where the estimation method is the GLS (Generalized Least Square) method. This method has calculated the heterogeneity contained in the independent variables explicitly so that this method can prevent heteroscedasticity in order to continue to get unbiased, consistent and efficient estimates (Musau, et al., 2015). Table 4 shows the results of the regression testing of each model. 
Table 4. Results of regression analysis

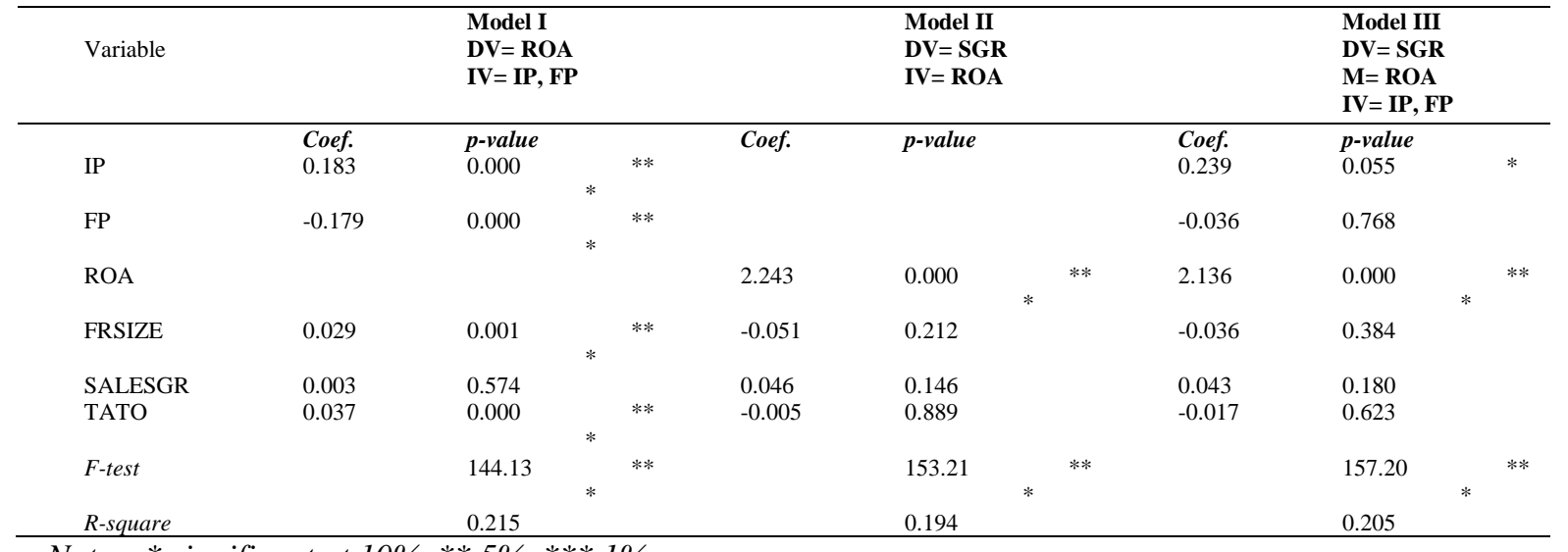

Notes: * significant at 10\%, ** 5\%, *** $1 \%$

Source: Secondary data processed

Model 1 predicts working capital policies can explain $21.5 \%$ of the variation in the dependent variable profitability. In the conservative current asset investment policy, the results of the analysis show that the conservative investment policy positively and significantly influences the profitability of the firm (Coef. $=0.183$; $\rho$-value $=0.000$ ). Whereas the short-term financing policy has a significant negative effect on profitability (Coef. $=-0.179 ; \rho$-value $=0.000$ ) means that if the firm is more conservative in short-term financing policies, the greater its effect on increasing profitability. Model 2 predicts that profitability can estimate $19.4 \%$ of the dependent variable variation in sustainable growth. The results of the analysis show that profitability has a positive and significant effect on sustainable growth (Coef. $=2,243 ; \rho$-value $=0,000$ ).

The results of testing model 1 and model 2 indicate that profitability can act as a mediating variable the effect of working capital policy on SGR. Furthermore, Model 3 is used to analyze whether there is a full or partial mediation effect. The results of the analysis show the influence of positive and significant current asset investment policies on sustainable growth $($ Coef. $=0.239, \rho$-value $=0.055)$ so that profitability is partially mediation. Meanwhile, the short-term financing policy does not significantly affect sustainable growth (Coef. $=-0.036 \rho$ value $=0.768)$ so that profitability plays a full role as a mediator. To strengthen the results of the analysis of the profitability mediation effect, the Sobel, Arorian, and Goodman tests are presented in Table 5. It appears that profitability can mediate the effect of current asset investment policies on sustainable growth. This is indicated by the significant results from the Sobel, Arorian, and Goodman tests $(\rho<0.01)$. Similar results also occur in shortterm financing policies.

Table 5 Mediation Effects

\begin{tabular}{|c|c|c|c|}
\hline & t-test & std-Error & p-value \\
\hline \multicolumn{4}{|l|}{ IP - ROA - SGR } \\
\hline Sobel test & 6.192 & 0.063 & $0.000 * * *$ \\
\hline Arorian test & 6.174 & 0.063 & $0.000 * * *$ \\
\hline Goodman test & 6.211 & 0.063 & $0.000 * * *$ \\
\hline \multicolumn{4}{|l|}{ FP - ROA - SGR } \\
\hline Sobel test & -6.195 & 0.062 & $0.000 * * *$ \\
\hline Arorian test & -6.177 & 0.062 & $0.000 * * *$ \\
\hline Goodman test & -6.213 & 0.061 & $0.000 * * *$ \\
\hline
\end{tabular}

\subsection{Discussion}

The higher the current assets proved the higher the profitability of the firm. This shows that conservative investment policies have a positive impact on firm profitability. This study is consistent with previous studies (Vahid et al., 2012; Wanguu, 2015; Rasyid et al., 2018; Sohail et al., 2016) which show a positive influence between conservative current asset investment policies and profitability. Manufacturing firms in Indonesia that tend to use conservative investment policies with an average proportion of current assets to total assets of $54.2 \%$ have chosen the appropriate policy to encourage increased profits. 
Short-term financing policy has a negative effect on firm profitability. The more short-term debt is likely to be the lower the profitability. Conversely, the less short-term debt is likely to be the higher the profitability. Thus, a conservative financing policy which means the more conservative the higher the profit earned. The average manufacturing firm in Indonesia has a proportion of current debt to total assets of $32.2 \%$ so that long-term debt becomes dominant as a source of financing. This study is in line with research (Nazir \& Afza, 2009; Vahid et al., 2012; Rasyid et al., 2018) which shows a positive relationship between conservative current debt financing policies and profitability. Although short-term debt is cheaper than long-term debt, there is a possibility that firms have to incur additional costs to increase current debt (Thakur \& Muktadir-al-mukit, 2017), firms have difficulty doing credit renewal (Baños-Cabalerro et al., 2016) and limited access to the capital market (Kaddumi \& Ramadan, 2012). The high cost of short-term debt can increase the cost of capital which will ultimately reduce the firm's ability to generate profits.

Profitability has a positive effect on SGR. As predicted the ability to generate profits will determine SGR. Given SGR depends on ROE and retention rate (Higgin, 1977). The results of this study are consistent with previous research which shows that profitability can affect a firm's sustainable growth (Amouzesh et al., 2011; Rahim, 2017; Nastiti et al., 2018). The greater the SGR, the greater the ability to provide internal financing to support firm growth. However, currently, the average SGR of manufacturing firms in Indonesia is only $1.9 \%$, making it a challenge for manufacturing firms themselves to increase.

This study proves the influence of conservative working capital policies on SGR through profitability. Firms can increase SGR by investing in higher current assets and utilizing long-term financing sources. Efforts to increase the SGR of manufacturing firms in Indonesia are important because on average they are still low. The firm can increase investment in receivables and inventories, which currently have an average proportion of $17.8 \%$ and $21.2 \%$, respectively. The receivables policy in the form of soft sales credit can increase sales and can also expand market share (Wilner, 2000) and the adequacy of inventory held will prevent the firm from stock-out (Corsten \& Gruen, 2004) to be crucial to increasing profits. Besides, firms can rely on long-term financing sources rather than short-term financing sources to increase SGR. This indicates that short-term financing from banks and suppliers is still an expensive source of financing, thereby reducing the company's ability to make a profit and ultimately have an impact on SGR.

\section{Conclusion}

This study investigates the links between conservative working capital policies, profitability, and SGR in manufacturing firms that became the backbone of Indonesia's economy in the 2013-2018 period. The study results show that conservative working capital policies have a positive effect on firm profitability. Firms with a proportion of current assets to a large total assets will tend to be able to have high profits. While in terms of financing, firms that have a low proportion of short-term financing or rely more on long-term financing tend to have high profits. Furthermore, profitability is proven to have a positive effect on SGR. The conservative working capital policy has also been proven to influence SGR through profitability.

This study contributes to expanding knowledge related to working capital policies. An important finding of this study is that conservative working capital policies can increase SGR through profitability. This relationship has not been a concern of previous studies. Working capital policy can be interpreted as having a strategic role in the sustainability of manufacturing firms in the long run. The results of the study also have practical implications for manufacturing firm managers. Firms can improve their performance by adopting conservative working capital policies including (a) adopting a loose sales credit policy; (b) have adequate supplies and (c) rely more on longterm financing not only for the investment of fixed assets but also for current assets. As with other studies, this study also cannot be separated with limitations. Among other things, this study has not investigated the possibility of a non-linear relationship between conservative working capital policies with profitability and sustainable growth. To a certain extent, the possibility of an increase in current asset investment and long-term financing is an increase in the cost of capital that is far greater than the level of the firm's ability to generate profits, so there is a possibility that conservative working capital policies will be counterproductive. Thus, future research is expected to address that issue.

\section{References}

Abdoli, M., Jalali, M., \& Sattari, B. 2013. The Study oh the Effect of the Working Capital Policies on the Risk and the Performance (Profitability) of the Enterprises. European Online Journal of Natural and Social Science, 2(3): 1-7.

Adam, A.M., Quansah, E., \& Kawor, S. 2017. Working Capital Management Policies and Returns of Listed Manufacturing Firms in Ghana. Scientific Annals of Economics and Business, 64(2): 255-269.

Ahmad, B., \& Samim, M.M. 2018. Working Capital Management Efficiency and Corporate Governance in Manufacturing Sector of Pakistan. European Online Journal of Natural and Social Science, 7(1): 67-87. 
Al-Shubiri, F.N. 2011. Analysis the Relationship between Working Capital Policy and Operating Risk: An Empirical Study on Jordanian Industrial Firms. Hebron University Research Journal, 6(1): 287-306.

Amouzesh, N., Moeinfar, Z., \& Mousavi, Z. 2011. Sustainable Growth Rate and Firm Performance: Evidence from Iran Stock Exchange. International Journal of Business and Social Science, 2(23): 249-255.

Ashta, A. 2008. Sustainable Growth Rates: Refining a Measure. Briefings in Entrepreneurial Finance, 214: $207-$ 214.

Bandara, R. 2015. Impact of Working Capital Management Policy on Market Value Addition. Global Journal of Contemporary Research in Accounting, Auditing and Business Ethics (GJCRA) An Online International Research Journal, 1(1): 344-373.

Baños-Cabalerro, S., García-Teruel, P.J., \& Martínez-Solano, P. 2016. Financing of Working Capital Requirement, Fiancial Flexibility and SME Performance. Journal of Business Economics and Management, 17(6): 1189-1204.

Corsten, D., \& Gruen, T.W. 2004. Stock-outs Cause Walkouts. Harvard Business Review, 82(5): 26-28.

Deloof, M. 2003. Does Working Capital Management Affect Profitability of Belgian Firms?. Journal of Business Finance \& Accounting, 30: 573-588.

Fonseka, M.M., Ramos, C.G., \& Tian, G.L. 2012. The Most Appropriate Sustainable Growth Rate Model for Managers and Researchers. Journal of Applied Business Research, 28(3): 481-500.

Gitman, L. J., \& Chad, J. Z. (2012). Principles of Managerial Finance, 13th Edition (13th ed.). Global Edition: Pearson Education Limited

Hassani, M.E., \& Tavosi, A.R. 2014. To Survey the Effect of Working Capital Policies (Investing \& Financing) on Profitability Risk (Evidence from Tehran Stock Exchange). Journal of Investment and Management, 3(1): 30-36.

Higgins, R. 1977. How Much Growth Can A Firm Afford?. Financial Management, 6(3): 7-16.

Islam, M.N. \& Mili, S.A. 2012. Working Capital Investment and Financing Policies of Selected Pharmaceutical Firms in Bangladesh. Research Journal of Finance and Accounting, 3(4):1-7.

Kaddumi, T.A., \& Ramadan, I.Z. 2012. Profitability and Working Capital Management: The Jordanian Case. International Journal of Economics and Finance, 4(4): 217-226.

Kishore, B., \& Pai, R.J. 2014. Impact of Aggressive and Conservative Working Capital Management Policy on Firms Profitability. Research Journal of Social Science and Management, 4(1): 105-110.

Kumar, A. 2018. Financial Distress and Sustainability Growth of Indian Banks Listed in BSE 30. Asian Research Journal, 7(6): 26-38.

Kumari, S. 2008. Multicollinearity: Estimation and Elimination. Journal of Contemporary Research in Management, 1(1): 87-95.

Manaf, N.B.A, Saad, N.B.M., Mohamad, N.E.A.B., Ali, I.B.M., \& Rahim, N.B. 2018. Determinants of Sustainability Growth Rate (SGR) by Using Zakon's Model to Encounter with Shariah Compliance Requirements for Shariah Securities Comliance Firms in Malaysia. International Journal of Industrial Management, 4(2018): 61-69.

Mukherjee, T. \& Sen, S.S. 2018. Sustainable Growth: A Study on Some Selected Banks in India. International Journal of Money, Banking and Finance, 6(1): 52-59.

Musau, V.M., Waititu, A.G., \& Wanjoya, A.K. 2015. Modeling Panel Data: Comparison of GLS Estimation and Robust Covariance Matrix Estimation. American Journal of Theoretical and Applied Statistics, 4(3): 185-191.

Mwangi, L.W., Makau, M.S., \& Kosimbei, G. 2014. Effect of Working Capital Management on Performance of Non-Financial Firms Listed in NSE, Kenya. European Journal of Business and Management, 6(11): 1952005 .

Nastiti, P.K.Y., Atahau, A.D.R., \& Supramono, S. 2019. Working Capital Management and Its Influence on Profitability and Sustainable Growth. Business: Theory and Practice, 20: 61-68.

Nazir, M.S., \& Afza, T. 2009. Impact of Aggresive Working Capital Management Policy on Firms' Profitability. The IUP Journal of Applied Finance, 15(8): 19-30.

Ogundipe, S.E., Idowu, A., \& Lawrencia. 2012. Working Capital Management, Firms' Performace and Market Valuation in Nigeria. World Academy of Science, Engineering and Technology, 6(1): 124-128.

Oloo, M.S., \& Mwangi, M.W. 2014. Effect of Aggressive Financing Policy on Profitability of Listed Firms at Nairobi Securities Exchange, Kenya. International Journal of Science and Research, 3(4): 444-448.

Palombini, N.N.V., \& Nakamura, W. 2012. Key Factors in Working Capital Management in the Brazilian Market. Revista de Administração de Empresas, 52(1): 55-69.

Panigrahi, A.K. 2014. Understanding the Working Capital Financing Strategy (A Case Study of Lupin Limited). Journal of Management Research and Analysis, 1(1): 100-102.

Puraghajan, A., Ramzani, A.A., \& Bin, I.E. 2014. Effect of Aggressive Working Capital on the Performance of Listed Firms in Tehran Stock Exchange. Kuwait Chapter of Arabian Journal of Business and Management Review, 3(7): 71-84.

Rădăşanu, A.C. 2015. Cash-flow Sustainable Growth Rate Models. Journal of Public Administration, Finance and Law, 7: 62-70. 
Raheman, A., Afza, T., Qayyum, A., \&Bodla, M.A. 2010. Working Capital Management and Corporate Performance of Manufacturing Sector in Pakistan. International Research Journal of Finance and Economics, 47: 151-163.

Rahim, N. 2017. Sustainable Growth Rate and Firm Performance: A Case Study in Malaysia. International Journal of Management, Innovation and Entrepreneurial Research, 3(2): 48-60.

Rasyid, R., Lukman, S., Husni, T., \& Adrimas. 2018. The Impact of Aggresive Working Capital Management Policy on Firms' Value: A Mediating Effect of Firm's Profitability. Journal of Business and Management Science, 6(1): 16-21.

Sohail, S., Rasul, F., \& Fatima, U. 2016. Effect of Aggresive and Conservative Working Capital Management Policy on Performance of Scheduled Commercial Banks of Pakistan. European Journal of Business and Management, 8(10): 40-48.

Thakur, O.A., \& Muktadir-al-mukit, D. 2017. Working Capital Financing Policy and Profitability: Empirical Study on Bangladeshi Listed Firms. British Journal of Economics, Management \& Trade, 17(1): 1-6.

Vahid, T.K., Mohsen, A.K., \& Mohammadreza, E. 2012. The Impact of Working Capital Management Policies on Firm's Profitability and Value: Evidence from Iranian Firms. International Research Journal of Finance and Economic, 88: 155-162.

Wanguu, K.C. 2015. The Effect of Aggresive Working Capital Policy on Profitability of Non-financial Firms Listed at Nairobi Securities Exchange. International Journal of Commerce \& Business Studies, 3(4): 15-24.

Wilner, B.S. 2000. The Exploitation of Relationship in Financial Distress: The Case of Trade Credit. The Journal of Finance, 55(1): 153-178 